\title{
Effects of Banking Sector Reforms on the Relationship between Banking Stocks and the Stock Market Capitalization Rate in Nigeria
}

\author{
Bako Sunday Samuel ${ }^{1}$, Yahaya Shagaiya Daniel ${ }^{2,}$ Isaac Jatau Katuka ${ }^{3}$ \\ Department of Mathematical Sciences, Kaduna State University Nigeria
}

\begin{abstract}
This paper examines the effect of banking sector reforms on the relationship between banking stocks and the stock market capitalization rate. Based on simple linear regression, Multiple linear regression and correlational analysis the results obtained showed that banking sector capitalization, and stock market capitalization rate decreases as government prevailing interest rate on deposit by commercial banks increases. The study further revealed that there is a negative relationship between banking sector reforms and the stock market capitalization rate. It was therefore recommended that the reforms by the Central Bank of Nigeria to sanitize the banking industry is welcome however, it has to be carefully implemented to ensure banks are better positions to perform their strategic roles in the Nigeria capital market.
\end{abstract}

Keywords: Stock market capitalization rate, banking reforms, banking sector capitalization, interest rate.

\section{Introduction}

Most studies suggest that the macroeconomic environment has an important effect on the stock market capitalization rate such as gross domestic product, exchange rate, interest rate, current account and money supply (Kurihara,2006;Ologunde et al,2006). The efficiency of the stock market capitalization rate and the effects of variables that determine the capitalization rate have preoccupied the minds of economist since they both play an important roles in influencing a country's economic development. The capital market is considered efficient if its price movement can guarantees an equitable distribution of income and suboptimal allocation of societal resources, (Bollerslev 2003).

It is incontrovertible that the banking system is the engine of growth in any economy, given its function of financial intermediation. Through this function, banks facilitate capital formation; lubricate the production engine turbines and promote economic growth. However, banks' ability to engender economic growth and development depends on the health, soundness and stability of the system. The need for a strong, reliable and viable banking system is underscored by the fact that the industry is one of the few sectors in which the shareholders 'fund is only a small proportion of the liabilities of the enterprise. It is, therefore, not surprising that the banking industry is one of the most regulated sectors in any economy. The primary objective of the reforms is to guarantee an efficient and sound financial system. The reforms are designed to enable the banking system develop the required resilience to support the economic development of the nation by efficiently performing its functions as the fulcrum of financial intermediation. Thus, the reforms were to ensure the safety of depositors' money, position banks to play active developmental roles in the Nigerian economy, and become major players in the sub-regional, regional and global financial markets.

Recently, the Nigerian capital market has become very volatile as a result of various banking sector reforms in an attempt to keep pace with the global economic phenomenon; this has caused a downward trend in the prices of stocks in the Nigeria stock exchange especially banking stocks. This downward trend in the prices of banking stocks must have had some effects on the capital market capitalization rate.

Financial reforms and attendant policy prescriptions are age-long phenomena. They represent the various transformations and policy adjustments and overhaul that are directed at the art, practice, and activities of financial institutions and markets overtime in response to the nominal need for operational improvement and growth of both the institutions and the general economy. They could be internal or external in nature, reflecting critical-cum -comprehensive amendments, restructuring, and/or additions to the existing body of laws, guidelines and policies (Chinedu and Muoghalu 2004). In Nigeria, the ability of the financial subsector to play its role has been periodically punctuated by its vulnerability to systemic distress and macro-economic volatility, and policy fine tuning inevitability (Kama 2006). Consequently, the financial reforms were focused on further liberalization of banking business; ensuring competition and safety of the system; and proactively positioning the industry to perform the role of intermediation and playing a catalytic role in economic development. 


\section{Statement of the problems/objectives}

In Nigeria's economic history, the strides of the last few years, which have been internationally acclaimed, was unprecedented. The many reforms that have engendered the current success have largely included those in the financial sector, particularly, the positive policy shifts in the domestic money market as a first step towards a more robust and enduring facilities for the sector. Parts of the expectations are that the improved enabling environment from the reforms would continue to make more investment funds readily available through savings in the capital market. Given this sordid financial crisis, since 1988 many emerging economies, including Nigeria, embraced banking sector reforms. Starting in 1986, Nigeria's financial system began to be deregulated and by 1992, substantial changes had taken place. Consistent with trends in other developing countries, institutions and markets are growing and developing, leading to an increasing role being played by the financial system in the development of Nigeria's economy (Onwioduokit 2006). In July 2004, the "mother" of reforms came in when 89 banks were forced to merge culminating in 25 universal banks. This was further reduced to 24 banks at the end of December 2007 with the emergence of Stanbic Bank Plc. and IBTC Bank to form Stanbic IBTC Bank Plc.

Considering that there were 89 banks and the capital requirement of N25 billion and the time frame allocated for banks to recapitalize, it seems rationale to investigate the effects of the Nigeria banking sectors reforms on the stock market capitalization rate.

Thus, the general objective of the study is to investigate in an empirical manner, the effects of banking sector reforms in Nigeria on the relationship between stock market capitalization rate and interest rate as well as banking stocks capitalization rate in the Nigeria stock exchange market. For example, the CBN declaration of $14^{\text {th }}$ August 2009 declaring 8 out of the 24 banks as technically insolvent as a result of a stress test carried out by the CBN who regulates banking operations in Nigeria will have some causal relationship between the stock market capitalization rate and the capitalization of banking stocks.

The specific objectives are;

a. To assess the relationship between stock market capitalization rate and prevailing interest rate.

b. To assess the relationship between banking stocks capitalization rate and the total capitalization rate of the Nigeria Stock Exchange (NSE).

c. To examine the relationship between banking stock capitalization and the prevailing interest rate.

d. To ascertain the impact of recent banking reforms on the stock market capitalization rate.

\section{HYPOTHESES}

i) $\mathrm{H}_{1}$ : There is a negative relationship between stock market capitalization rates and prevailing interest rate.

ii) $\mathrm{H}_{2}$ : Banking stock capitalization rate are not a significant explanatory factor of the variation of the total capitalization rate on the NSE.

iii) $\mathrm{H}_{3}$ : There is a negative relationship between banking stock capitalization rate and prevailing interest rate.

iv) $\mathrm{H}_{4}$ : There is a negative relationship between banking sector reforms and stock market capitalization rate.

\section{Literature Review and Conceptual Framework}

Ologunde et al (2006) examined the relationships between stock market capitalization rate and interest rate in Nigeria. They used the ordinary least -square (OLS) regression method and they found that the prevailing interest rate exerts positive influence on stock market capitalization rate. Also, they are finding that Government development stock rate exerts negative influence on stock market capitalization rate and prevailing interest rate exerts negative influence on government stock rate.

Mahmudul and Gazi (2009) in their study (based on the monthly data from January 1988 to March 2003)found that interest rate exerts significant negative relationship with share price for markets in Australia, Bangladesh, Canada, Chile, Colombia, Germany, Italy, Jamaica, Japan, Malaysia, Mexico, Philippine, South Africa, Spain, and Venezuela .For six countries from this sample, they argued on the availability of significant negative relationship between changes of interest rate and changes of share price.

Ayedemir and Demirhan (2009) studied the causal relationship between stock prices and exchange rates, using data from 23 February 2001 to 11 January 2008 for Turkey. Their empirical research found the bidirectional causal relationship between exchange rate and financial all stock market indices. While the negative causality exist from national 100 service, financial and industrial indices to exchange rate, there exists a positive causal relationship from technology sector indices to exchange rate. On the other hand, negative causal relationship from exchange rate to all stock market indices is determined.

\subsection{Factors Determining Stock Prices in Nigeria}

A lot of factors have been identified to influence the price determination of securities in the Nigeria stock market. For clarity and understanding we discussed them here under the primary and secondary market. 


\section{i) THE PRIMARY MARKET:}

The primary market is a market on which new financial securities are initially traded. Issuing house based on the recommendation and guidelines issued by the Security and Exchange Commission (SEC) first determines the price of the newly quoted company's share in the primary market. The issuing house collate all relevant data of the company including its wealth of assets, historical performance, its control of market share, ability to hire and retained efficient and seasoned management hands, the strength to diversify or innovate, present and future prospects for the industry and most importantly its Net Asset value and the maintainable annual profit.

Based on these factors as approved by SEC the first price at which an ordinary share of that company is offered to the public for subscription is set. There is normally no price movement during the life span of primary issues which may last for a minimum of three weeks.

After the closure of the primary offer, shares are allotted and share certificate are process and remitted to beneficiaries accordingly. Then the company's share listed on the stock market through the approval of the council of the Nigerian Stock Exchange for trading purposes.

\section{ii) THE SECONDARY MARKET:}

The secondary market is the market for resale of shares. This is distinct from the market for new issues: the vast majority of dealings in shares are in secondary markets. The existence of a liquid secondary market for shares is an important factor in making them saleable as new issues. If people intending to buy newly issued shares knew they could not sell them readily, but had to retain them permanently, they would be much more reluctant to risk buying them in the first place.

The primary market exercise, having completed, the company shares are listed on the stock market, at the same SEC prices that were offered to the public for subscription in the primary market. The shares will then be available for trading. At this stage, the values of the company's shares are determined to certain extent, by market forces as opposed to the rigid formalistic negotiations between the company and its advisers on the one hand and the SEC on the other.

Several factors that affect the price movement of quoted company's shares in the secondary market were identified. The combine effects of these factors are reflected in the demand and supply. Such factors may be associated with the company, governmentpolicies, the Nigeria Stock Exchange, the Stock Brokers and the general market factors such as standardized industrial rations, Discriminatory acceptability of share certificates as collaterals for loan by banks, availability of risk less trading option in Nigeria market, paucity of viable equity share in the market etc.

\section{Model, Data and Methodology}

This study is a regression and correlational descriptive research that attempts to understand the effects of banking sector reforms on the relationship between interest rate and stock market capitalization rate as well as between interest rate and banking stock capitalization rate. The study uses data from the Nigeria Stock Exchange Facts Books, Central Bank of Nigeria and the Security and Exchange Commission statistical bulletin. The data covered the period 1999 to 2008.

In order to estimate the stock market capitalization rate (S) and banking stock capitalization (B) the following basic linear models of (S) and (B) are specified

$$
\begin{aligned}
& \text { Model(1): } S=a_{0}+a_{1} \mathrm{R}+a_{2} \mathrm{~B}+e_{t} \\
& \quad \text { Model(2): } S=b_{0}+b_{1} R+e_{t} \\
& \quad \text { Model(3): } B=c_{0}+c_{1} R+e_{t}
\end{aligned}
$$

Where

$S=$ stock market capitalization rate

$R=$ prevailing interest rate

$B=$ banking stock capitalization rate

$e=$ error term

$a, b, u=$ constant.

The data obtained were fitted to the equations by ordinary least-square (OLS) regression method. The linear relationship between the dependent and independent variables were determined. Inferences were drawn based on the correlation and regression analysis carried out.

\subsection{Presentation of Data}

\section{Results and Discussions of Results}

Table 1: Market capitalization of the Nigerian Stock Exchange and prevailing interest rate on deposit by commercial banks. 


\begin{tabular}{|c|c|c|c|}
\hline Year & Market capitalization(\#M) & $\begin{array}{l}\text { Banking sector market } \\
\text { capitalization(\#M) }\end{array}$ & $\begin{array}{l}\text { Prevailing interest rate } \\
(\%)\end{array}$ \\
\hline 1999 & 300041 & 54.6 & $\begin{array}{ll} & 6.6 \\
\end{array}$ \\
\hline 2000 & 472290 & 135.053 & 4.9 \\
\hline 2001 & 662561 & 200.4 & 5 \\
\hline 2002 & 7664976 & $\mathrm{Na}$ & 3.7 \\
\hline 2003 & 1359274 & 218 & 3.2 \\
\hline 2004 & 2112550 & 469 & 4.4 \\
\hline 2005 & 2900062 & 964 & 3.3 \\
\hline 2006 & 5120000 & 1980000 & 3 \\
\hline 2007 & 13300000 & 5148000 & 3.2 \\
\hline 2008 & 9560000 & 5654000 & 3.6 \\
\hline
\end{tabular}

SOURCE: Nigerian Stock Exchange Fact Books, Central Bank of Nigeria and Security and Exchange Commission statistical Bulletin. Na-Not Applicable.

\subsection{Discussion of results}

I) Correlation and regression coefficients: Prevailing interest rate and banking sector market capitalization on stock market capitalization.

Table 2: Correlation coefficients

\begin{tabular}{|l|l|l|l|l|}
\hline & \multicolumn{1}{|c|}{$S$} & \multicolumn{1}{c|}{$B$} & \multicolumn{1}{c|}{$R$} \\
\hline $\begin{array}{l}\text { Stock market } \\
\text { capitalization }(S)\end{array}$ & 1.000 & 0.950 & -0.575 \\
\hline $\begin{array}{l}\text { Banking sector market } \\
\text { capitalization }(B)\end{array}$ & 0.950 & 1.000 & -0.446 \\
\hline Prevailing interest rate $(R)$ & -0.572 & -0.446 & 1.000 \\
\hline
\end{tabular}

\section{SOURCE: SPSS OUTPUT FILE}

Table 2 above outlines the correlation coefficients between the dependent variable represented by stock market capitalization rate $(S)$ and the independent variables which include banking sector market capitalization $(B)$ and prevailing interest rate $(\mathrm{R})$ on deposits by commercial banks. The main objective here is measuring the strength or degree of linear relationship between the variables. The negative relationship between $S$ and $R$ and $B$ and $R$ implies that as interest rate increases, stock market capitalization rate $(S)$ and banking sector market capitalization $(B)$ rate decreases and the size of the stock exchange reduces. Hence, economic growth and development is retarded .The reduction in the trading volume of the stock exchange is as a result of the willingness of investors to invest in businesses with good profit and turnover while being risk averse since as interest rate increases, investors will prefer to invest in the banks than to invest in the stock market.

The result also shows a strong positive correlation between $S$ and $B$, this implies that a fall in investors' confidence to invest in banking stock will have an adverse effect on the stock market capitalization rate. This result also supports the empirical evidence from the global financial crisis; hence from the regression results and analysis carried out, $\mathrm{H}_{2}$ is statistically significant, we therefore fail to accept $\mathrm{H}_{2}$ which states that banking sector market capitalization are not a significant explanatory factor of the variation of the total market capitalization.

From the results obtained the positive linear relationship between $S$ and $B$ shows that as the banking sector market capitalization increases, the stock market capitalization rate also increases. The negative relationship between stock market capitalization and interest rate implies that as interest rate increases, stock market capitalization rate decreases with a concomitant decrease in the Net present value (NPV) of the stock exchange and therefore a reduction in the size of the exchange. This means economic growth and development will be retarded. The reason for this relationship lies in the fact that investors are willing and will always commit their funds(invest) in the bank or other businesses with good profit and quick turnover while taking less risk than invest in the stock exchange.

Table 3: Regression coefficients: Prevailing interest rate and Banking sector market capitalization on Stock market capitalization rate.

\begin{tabular}{|l|l|l|l|l|l|}
\cline { 2 - 5 } \multicolumn{2}{c|}{} & Unstandardized Coefficient & \multicolumn{2}{l}{$\begin{array}{l}\text { Standardized } \\
\text { Coefficients }\end{array}$} & \multicolumn{2}{l}{ Sig. } \\
\hline Model & B & Std. Error & Beta & T & 0.093 \\
\hline constant & 4319557.089 & 2167911.022 & & 1.992 & 0.000 \\
\hline $\begin{array}{l}\text { Banking sector } \\
\text { Capitalization }\end{array}$ & 1.698 & 0.239 & 0.872 & 7.091 & 0.206 \\
\hline $\begin{array}{l}\text { Prevailing } \\
\text { Interest rate }\end{array}$ & -666690.428 & 469685.995 & -0.175 & -1.419 & \\
\hline
\end{tabular}


$R=0.963, R^{2}=0.927, R^{2}$ (adj.) $=0.903$, S.E $=1.42538 \mathrm{E} 6$

Table 3 shows the result of regression analysis output between the dependent variable, (stock market capitalization) and the independent variables (banking sector market capitalization and the government prevailing interest rate on deposit by commercial banks). The value of co-efficient of correlation (0.963) between the dependent and independent variables shows a strong positive correlation. The co-efficient of determination of $92.7 \%$ indicates that $92.7 \%$ of the total variation in the stock exchange is accounted for by banking sector market capitalization and the prevailing interest rate of deposits by commercial banks, while the remaining $7.3 \%$ is accounted for by the variables not included in our model. The R square of $92.7 \%$ tells us that the model's fit is good. Thus we fail to accept $\mathrm{H}_{1}$ that there is a negative relationship between stock market capitalization rate and the prevailing interest rate. The regression equation is;

$$
S=4319557.089-1.698 B-666690.420 R+e
$$

Table: 4: Analysis of Variance (ANOVA) for the regression equation

\begin{tabular}{|l|l|l|l|l|l|}
\hline Model & Sum of squares & D.F & Mean square & F & SIG \\
\hline Regression & $1.555 \mathrm{E} 14$ & 2 & $7.774 \mathrm{E} 13$ & 38.263 & 0.000 \\
\hline Residual & $1.219 \mathrm{E} 13$ & 6 & $2.032 \mathrm{E} 12$ & & \\
\hline Total & $1.677 \mathrm{E} 14$ & 8 & & & \\
\hline
\end{tabular}

SOURCE: SPSS OUTPUT FILE

Table 4 is the ANOVA result for the regression equation. It enables us to test the overall significance of the regression equation.

Since the p-value of 0.000 from the Analysis of Variance for the regression equation is statistically significant at the 5\% level of significance, we therefore have strong evidence not to accept both $\mathrm{H}_{1}$ and $\mathrm{H}_{2}$.

Table 5: Regression coefficient: Prevailing interest rate on banking Sector market capitalization.

\begin{tabular}{|l|l|l|l|l|l|}
\cline { 2 - 5 } \multicolumn{1}{c|}{} & \multicolumn{2}{l|}{ Unstandardized Coefficient } & $\begin{array}{l}\text { Standardized } \\
\text { Coefficient }\end{array}$ & \multicolumn{2}{c|}{} \\
\hline Model & B & Std. Error & Beta & T & Sig \\
\hline Constant & $1.353 \mathrm{E} 7$ & 4818032.429 & & 2.808 & 0.023 \\
\hline $\begin{array}{l}\text { Prevailing } \\
\text { interest rate }\end{array}$ & -2245167.937 & $1138947.92 \mathrm{H}$ & -0.572 & -1.971 & 0.084 \\
\hline
\end{tabular}

\section{SOURCE: SPSS OUTPUT FILE}

$\mathrm{R}=0.572, R^{2}=0.327, R^{2}$ (adj.) $=0.243$, S.E of Estimate $=3.89064 \mathrm{E} 6$

Table 5 gives the regression coefficient of the government prevailing interest on deposit by commercial banks on the banking sector market capitalization rate. The value of the coefficient of correlation between the independent variable (prevailing interest rate) and the dependent variable (stock market capitalization rate) of 0.572 shows a fairly weak negative correlation between S and R. The coefficient of determination of $32.7 \%$ indicates that $32.7 \%$ of the variation in market capitalization is explained by the prevailing interest rate while $67.3 \%$ are explained by other variables not included in the model. The negative relationship between $S$ and $R$ implies that as interest rate increases, stock market capitalization rate decreases, investors will prefer to invest in the banks or other less risky businesses than invest in the stock exchange. Thissupports our result obtained from table 4.2.2 and hence we fail to accept $\mathrm{H}_{1}$ that there is a negative relationship between stock market capitalization rate and the prevailing interest rate. This result is similar with what was obtained by (Ologunde et al, 2006) and (Husni et al, 2010).

The regression equation becomes,

$$
S=1.353 E 7-2245167.937 R+e
$$

\begin{tabular}{|c|c|c|c|c|c|}
\hline & \multicolumn{2}{|c|}{ Unstandardized Coefficients } & \multirow{2}{*}{$\begin{array}{l}\text { Standardized } \\
\text { coefficients } \\
\text { Beta }\end{array}$} & \multirow[b]{2}{*}{$\mathrm{T}$} & \multirow[b]{2}{*}{ Sig. } \\
\hline Model & B & Std. Error & & & \\
\hline Constant & 5037919.516 & 2842518.562 & & -1.772 & 0.120 \\
\hline $\begin{array}{l}\text { Prevailing } \\
\text { interest rate }\end{array}$ & -875194.478 & 663346.879 & -0.446 & -1.319 & 0.229 \\
\hline
\end{tabular}

Table 6: Regression coefficient: Prevailing interest rate on banking sector market capitalization.

\section{SOURCE: SPSS OUTPUT FILE}

$R=-0.446, R^{2}=0.199, R^{2}$ (adj. $)=0.085$, S.E of Estimate $=2.24952 \mathrm{E} 6$

The result from table 6 shows that interest rate exert a negative relationship on banking sector market capitalization, as the interest rate increases, investors will prefer to invest in other businesses than to invest in 
banking stocks, consequently, a decrease in the interest rate will lure investors to invest in the banking stock rather than invest in other business.

The value of coefficient of correlation is- 0.446 which shows a negative relationship between the dependent and independent variables. The coefficient of determination of $19.9 \%$ indicates that $19.9 \%$ of the variable in market capitalization has been explained by the prevailing interest rate, while the remaining $80.1 \%$ are explained by some other variables not included in this model.

From our regression analysis result, the data provides evidence that leads to our failure to accept $\mathrm{H}_{3}$ that there is a negative relationship between $S$ and $R$.

The regression equation is,

$$
B=5037919.516-875194.516 R+e
$$

II) Correlation and regression coefficients o0f the banking market sector capitalization and the stock market capitalization rate 1999-2004 to 2005-2008.

The period 1999-2004 will be called the pre-announcement period; this is the period before the regulatory change on the banking recapitalization consolidation. The period 2005-2008 is the period in which the consequence of the regulatory change becomes publicly known by investors and the implementation also takes effect.

Table 7: Regression coefficient: Banking sector market capitalization on stock market capitalization 1999-2004

\begin{tabular}{|l|l|l|l|l|l|}
\cline { 2 - 5 } \multicolumn{2}{c|}{} & \multicolumn{2}{l}{$\begin{array}{l}\text { Unstandardized } \\
\text { Coefficient }\end{array}$} & $\begin{array}{l}\text { Standardized } \\
\text { Coefficient }\end{array}$ & \multicolumn{3}{l|}{} \\
\hline Model & B & Std. Error & Beta & T & Sig \\
\hline Constant & -4097.833 & 223343.970 & & -0.018 & 0.987 \\
\hline Banking & 4574.710 & 870.863 & 0.950 & 5.253 & 0.013 \\
\hline
\end{tabular}

\section{SOURCE: SPSS OUTPUT FILE}

$\mathrm{R}=0.950, R^{2}=0.902, R^{2}$ (adj.) $=0.869, \mathrm{~S} . \mathrm{E}$ of Estimate $=2.71029 \mathrm{E} 5$

Table 7 gives the result of the regression output for the banking sector market capitalization (B) on the stock market capitalization rate (S) for the year 1999-2004.The coefficient of variation of $90.2 \%$ indicates the variation in the market capitalization explained by the banking sector market capitalization. The remaining $8.8 \%$ are variation due to other factors not included in the model. The correlation of $95 \%$ shows a strong positive linear relationship between the banking market sector capitalization and the stock market capitalization rate.

The regression equation is,

$$
S=4097.833+4574.710 B+e
$$

Table 8: Regression coefficients: Banking stock on stock capitalization 2005-2008

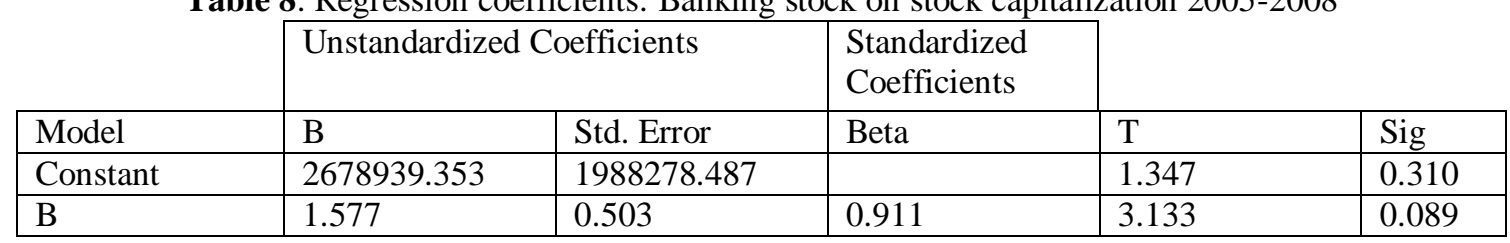

SOURCE: SPSS OUTPUT FILE

$\mathrm{R}=0.911, R^{2}=0.831, R^{2}$ (adj.) $=0.746 \mathrm{~S} . \mathrm{E}$ of Estimate $=2.33648 \mathrm{E} 6$

Table 8 gives the result of the regression output for the banking sectormarket capitalizationon

stock market capitalization rate for the year 2005-2008. The coefficient of variation of $83.15 \%$ indicates the variation in the market capitalization explained by the banking sector market capitalization. The remaining $16.85 \%$ are variation due to other factors not included in the model. The correlation of $91.1 \%$ shows a strong positive linear relationship between the banking market sector capitalization and the stock market capitalization rate. The regression equation is,

$$
S=2678939.353+1.577 B+e
$$

From tables 7 and 8 , It is expected that the coefficient of determination and the correlation coefficient should increase from 1999-2004 to 2005-2008 due to the various reforms and its impact in strengthening the banking sector, this was however not the case. This does not necessarily implies that the banking reforms does not strengthen the relationship between $S$ and $B$, but that the global financial meltdown also affected both the banking market capitalization and the stock market capitalization rate hence, the banking reform helps to cushion an outright fall in the stock market capitalization because banking stocks explain a greater percentage of the variation in the total stock market capitalization rate than any other variables in the NSE as seen from our regression results. The regression results for both periods further confirms the positive relationship between $S$ and $B$ as earlier stated, the impact of a one unit increase in the banking stock market capitalization is however 
higher for the period 1999-2004 than 2005-2008 despite the various reforms in the banking sector. This trend is not unconnected with the global financial meltdown which also affected the Nigerian stock exchange.

From our regression result for both period, banking market sector capitalization and stock market capitalization rate are positively related for the two period (1999-2004, and 2005-2008) but the relationship is more positive for the period 1999-2004.This is not to say that the regulatory change has not improved the relationship, but rather, the global financial meltdown also affected the prices of banking stocks as well as the stock market capitalization rate. Thus, based on our regression results for the period 1999-2004 and 2005-2008 taking the global financial meltdown that affected the prices of stocks into consideration, we fail to reject hypothesis $\mathrm{H}_{4}$ which states that there is a negative relationship between banking sector reforms and stock market capitalization rate.

\section{Summary, Conclusions and Recommendations}

\subsection{Summary of Findings}

The Nigerian banking sector could be said to have thrived over the years; witnessing changes in Governments and their accompanying policies which have egged and spurred its growth and development bringing it to the remarkable pedestal and international acclaim and goodwill it presently enjoys. This study therefore investigates examines the effects of banking sector reforms on the relationship between stock market capitalization rate, banking stock market capitalization and prevailing interest rate. The study is a correlational descriptive research that attempts to understand the nature of the relationship that exists between these variables. The study therefore employs the ordinary least square regression method.

The analysis begins by fitting the regression model of banking stock market capitalization, and prevailing interest rate on the total stock market capitalization rate. The result revealed that as the banking sector market capitalization $(B)$ increases, the stock market capitalization rate $(S)$ also increases signifying a positive relationship between $B$ and $S$. The result also revealed that as interest rate increases, stock market capitalization rate decreases with a decrease in the Net Present Value (NPV) of the stock exchange and therefore a reduction in the size of the exchange, thus, there is a negative relationship between stock market capitalization and prevailing interest rate.

For the relationship between banking sector market capitalization and prevailing interest rate $(R)$, we fix a regression model of $R$ on $B$. The result obtained revealed that interest rate exerts a negative relationship on banking sector market capitalization, consequently, as the interest rate increases, investors will prefer to invest in other businesses or in the bank than to invest in either the stock exchange. The correlation coefficients were also obtained and the result shows a high positive correlation between $S$ and $B$, and a negative correlation between $S$ and $R$, and, $B$ and $R$.

To investigate the nature of the relationship between banking sector reforms and the stock market capitalization, the data was split into two; 1999-2004 and 2005-2008. Where the period 1999-2004 is the period before the regulatory change on banking recapitalization/consolidation, and the period 2005-2008 is the period in which the effect of the regulatory change becomes publicly known by investors and also the implementation of the regulatory change came into effect. The result obtained revealed that there is a positive relationship between $S$ and $B$, that is an increase in the banking sector market capitalization also leads to an increase in the total stock market capitalization, however, the long term effect for the periods under review, shows that the effect of $B$ on $S$ is higher for the period 1999-2004 than for 2005-2008 despite the positive reforms, this downward trend can be attributed to the global financial meltdown that also affected the Nigeria stock exchange. Hence, if the reforms were not to have been implemented, the effect of global financial crisis on the Nigeria stock exchange would have been more colossal. We therefore conclude from our results that there is a negative relationship between banking sector reforms and the stock market capitalization rate based on the regression results for the periods 1999-2004 to 2005-2008 taking into consideration the global financial meltdown that affected the prices of stocks in the Nigeria stock exchange.

\subsection{Conclusions}

In Nigeria, the major objectives of banking reforms are to strengthen the financial sector so that they act as reliable catalysts of economic growth and development. To achieve these objectives, the monetary authorities adopt a variety of policy instruments; however, in using these policy instruments, there would always be a conflict of other competing objectives. How successful banking reforms turns out to be in influencing economic growth will depend on the extent to which conflicts of banking and monetary policies are managed and the extent to which market forces are left to determine economic growth.

Conceptually, economic reforms are undertaken to ensure that every part of the economy functions efficiently in order to ensure the achievement of macroeconomic goals of price stability, full employment, high economic growth and internal and external balances. Thus, banking reform in Nigeria is an integral part of the country-wide reform program undertaken to reposition the Nigerian economy to achieve the objective of 
becoming one of the 20 largest economies by the year 2020. As part of the vision, the banking sector is expected to effectively play its actual role in intermediation and for the banks to be among global players in the international financial markets. The recent experience from the global financial crisis has further underscored the imperatives of countries to embark on banking reforms on a regular basis. The global financial crisis of 2007-2009 that resulted to the global recession led to the collapse of many-renowned financial institutions and capital markets. The financial reforms in Nigeria have brought about a new mindset to the industry as banks are putting in place best practices in the area of corporate governance and risk management. Transparency and public disclosure of transactions have remarkable improved and a number of banks have returned to the profitmaking path and improved their balance sheets, as the recent results of their financial statement have shown. The Nigerian economy has huge potential for growth. To realize this potential, it is imperative that we learn lessons from the crisis and take steps to not only fix the problems, but to also introduce measures to establish financial stability, a healthy evolution of the financial sector and ensure the banking sector contributes to the development of the real economy.

\subsection{Recommendations}

For the banking sector reforms in Nigeria to make lasting impacts on the Nigeria capital market, the following recommendations are put forward;

- The regulatory authorities of the capital market of Nigeria such as the securities and exchange commission (SEC) and the Nigeria stock exchange (NSE) must continue to make concerted efforts towards cushioning the effects of the global financial meltdown on the Nigerian Stock Exchange which has significantly affected its performance. This will help to restore investor's confidence and revival in the market.

- The current reforms by the Central Bank of Nigeria(CBN) to sanitize the banking industry is welcome; however, it has to be carefully implemented to ensure banks are better position to perform their strategic roles in the Nigerian capital market and the economy.

- Banks must also channel the funds raised from the market into profitable investment ventures that will maximize the shareholder's capital and increase the value of the banks.

- The Nigeria banking reforms despite its laudable achievements is confronted with certain challenges. Foremost is the wrong perception of the intent of the reform. The introduction of the new banking models, especially specialized banking (non-interest banking), has been given a religious connotation. The wrong perception and stiff resistance to the policy could potentially deter prospective investors in the banking industry. The CBN should therefore embark on aggressive publicity and enlightenment on the imperatives of non-interest banking.

- The importance of microfinance in a growing economy cannot be over-emphasized, given its potential in addressing the challenges of excluding a large population from full participation in economic activities .The CBN therefore, should sustain the Microfinance Development Fund (MDF) established which is aimed at improving access to affordable and sustainable sources of finance by Microfinance Institutions (MFIs) and Microfinance Banks (MFBs). This would enhance their operations and outreach and support the capacity building activities of the MFBs/MFIs.

- The government should favorably control interest rate so as to aid the growth of the stock market.

- Beyond the need to recapitalize the banks, the regulatory reforms should also focused on the followings;

i. Risk-focused and rule-based regulatory framework.

ii. Zero tolerance in regulatory framework in data/information rendition and infractions.

iii. Strict enforcement of corporate governance principles in banking.

iv. The introduction of a flexible interest rate based framework that will make the monetary policy rate the operating target. This will enable the banks to be proactive in countering inflationary measures.

v. Revision and updating of relevant laws for effective corporate governance and ensuring greater transparency and accountability in the implementation of banking laws and regulations.

\section{References}

[1] Al Faki M (2006). "The Nigerian Capital Market and SocioeconomicDevelopment". Public Lecture Presented at the 4th Distinguished Faculty of Social Sciences, University of Benin on 26 July, 2006.

[2] Alufe, F (2005). "A Review of Nigerian Capital Market. A Year of Mega Offers". Financial Standard

[3] Ayedemir, O., Demirhan, E., 2009. "The relationship between stock prices and exchange rates: Evidence from Turkey," International Research Journal of Finance and Economics, Issue 23, pp.207-15.

[4] Bollerslev, T (2001), "Financial Econometrics: Past development and future challenges" Journal of Econometrics Vol.100, pp41-51

[5] Central Bank of Nigeria. Annual Reports for Years 1981 to 2000.

[6] Central Bank of Nigeria (2007); "Annual Report and Statement of Account: For the year ended $31^{\text {st }}$ December, 2006"

[7] Central Bank of Nigeria (2007); Statistical Bulletin, Volume 18

[8] Central Bank of Nigeria (2009); “Annual Report and Statement

[9] Chinedu BE, Muoghalu MI 2004 Financial Reforms and Commercial Banks Operators in Nigeria: A comparison of Two Decades. Union Digest, 8: 2 . 


\section{Effects of Banking Sector Reforms on the Relationship between Banking Stocks and the Stock Market}

[10] Donwa P; Odia, J (2011). "Effects of Consolidation of the Banking Industry on the Nigerian Capital Market". J Economics Vol.2 pp.57-65.

[11] Izedonmi, FI (2005). "Bank recapitalization and merger option: Response calls to Basel I\& II Accords". The New Accountant, 1: 23 31.

[12] Kama U.(2006). Recent Reforms in the Nigerian Banking Industry: Issues and Challenges. CBN Bullion, $30: 3$.

[13] Koutsoyiannis A. (1977). Theory of Econometrics. (2nd Edition) London: Macmillan Press Ltd.

[14] Nigerian Stock Exchange: Annual Reports (1981-2000).

[15] Journal of African Economics and Finance - Issue 1(2011) 69

[16] Kurihara, Y., (2006). "The relationship between exchange rate and stock prices during the quantitative easing policy in Japan," International Journal of Business, Vol. 11, No4, pp.375-86.

[17] Madura, J.,(2001). "Financial markets and Institutions", South Western college publishing.

[18] Mahmudul, A., Gazi Salah, U., (2009). "The relationship between interest rate and stock price: Empirical evidence from developed and developing countries," International Journal of Business and Management, Vol. 4, No 3, pp.43-51.

[19] Nigerian Capital Market Statistical Bulletin 2010.

[20] Ologunde, A., Elumilade, D., Saolu, T., (2006). "Stock market capitalization and interest rate in Nigeria: A time series analysis," International Research Journal of Finance and Economics, Issue 4, pp.154-67.

[21] Onwioduokit E (2006). Financial Liberalization and Savings Mobilization in Nigeria. CBN Bullion, $30(1): 52$ - 62.

[22] Osaze, BE (2000). "The Nigerian Capital Market in the African and Global Financial System”. Benin City: Bofic Consulting Group Ltd.

[23] Salako, T (2005). "Consolidating the Banking Stocks". Financial Standard, Vol. 6, January 30, P. 35.

[24] Sanusi, LS (2012). "Banking Reforms and its impact on the Nigerian Economy". Lecture delivered at the University of Warwick's Economic summit, UK, February, 2012.

[25] Soludo, CC (2006). “Can Nigeria be the China of Africa?".Lecture Delivered at the University of Benin Founders' Day, November 2006, P.14.

[26] The Nigerian Stock Exchange and you (1998). Presentation Notes. Lagos: the Nigerian Stock Exchange.

[27] Zhou, L. and Mathew, T. (1993). Hypotheses tests for variance components in some multivariate mixed models. Journal of Statistical Planning and Inference, 37, 215- 227. 